\title{
TOWARDS A RESPONSE-ABLE PEDAGOGY ACROSS HIGHER EDUCATION INSTITUTIONS IN POST-APARTHEID SOUTH AFRICA: AN ETHICO-POLITICAL ANALYSIS
}

\section{Vivienne Bozalek}

University of the Western Cape

vbozalek@uwc.ac.za

\section{Michalinos Zembylas}

Open University of Cyprus and University of the Free State

m.zembylas@ouc.ac.cy

\section{ABSTRACT}

Internationally there has been some interest in how critical pedagogies might be enabled in higher education to support transformative social agendas. Few writers, however, have theorised the ethico-political aspects of this effort from a feminist new materialist perspective. By focusing on the analysis of an inter-institutional collaborative course which was constructed across three disciplines and two differently positioned universities in Cape Town, South Africa, this paper examines the design of the course retrospectively from a feminist new materialist theoretical framing. In so doing, it moves beyond more traditional understandings of critical pedagogy to consider the design and student engagement with the course from the perspective of what we call "response-able pedagogies." Response-able pedagogies are not simply examples of the type of learning that can take place when power relations, materiality and entanglement are acknowledged; they also constitute ethicopolitical practices that incorporate a relational ontology into teaching and learning activities. We propose that ethico-political practices such as attentiveness, responsibility, curiosity, and rendering each other capable, constitute reponse-able pedagogies. The paper focuses on the transdisciplinary and interinstitutional course to consider how these ethico-political practices which constitute a response-able pedagogy might (be put to) work and how the students were both enabled and constrained by this design in terms of their responses to such ethico-political practices.

\section{UNISA

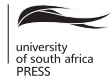

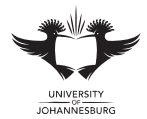

Education as Change 
Keywords: response-able pedagogies; critical pedagogies; relational ontology; feminist new materialism; ethico-political; social transformation; transdisciplinary; cross-institutional; higher education

\section{INTRODUCTION}

[D]iffractive readings must therefore entail close respectful responsive and response-able (enabling response) attention to the details of a text; that is, it is important to try to do justice to a text. It is about taking what you find inventive and trying to work carefully with the details of patterns of thinking (in their very materiality) that might take you somewhere interesting that you never would have predicted. It's about working reiteratively, reworking the spacetimemattering of thought patterns; not about leaving behind or turning away from. (Juelskaer and Schwennesen 2012, 13; our emphasis)

Hannah Arendt and Virginia Woolf both understood the high stakes of training the mind and imagination to go visiting, to venture off the beaten path to meet unexpected, non-natal kin, and to strike up conversations, to pose and respond to interesting questions, to propose together something unanticipated, to take up the unasked-for obligations of having met. This is what I have called cultivating response-ability. (Haraway 2016, 130; our emphasis)

In this paper, we focus on an inter-institutional course which was collaboratively designed across three disciplines and two differently positioned universities in South Africa. This course was conceptualised and implemented from 2006-2012 by educators who wished to address the issue of monocultural institutions in South Africa, as an inheritance of the apartheid past (Cooper, D. 2015), by bringing together students and teachers across disciplines and higher educational institutions (HEIs) in a new course. The challenge in developing this course was how to design a curriculum incorporating educational practices that might support transformative social agendas within the limiting structures of post-apartheid South Africa. Internationally, there has been some interest in how critical pedagogies - e.g. through the work of Freire (2000), Ellsworth (1989), Kumashiro (2002), McLaren (2003), and Giroux (2004), among others - might be enabled in HEIs to support social transformation (e.g. see Cooper, C. 2015; Martin 2017). Few writers, however, have theorised this effort from a feminist new materialist perspective to explore how we might actually put to work ethico-political educational practices that we refer to as response-able pedagogies. This paper sets out to look back retrospectively on this course to consider how students engaged with the course from the perspective of a response-able pedagogy.

The notion of response-ability is one which has been written about by feminist new materialist scholars such as Karen Barad (2007), Donna Haraway (1992, 1997, 2016) and Vinciane Despret (2004, 2016). Generally speaking, response-ability refers to the ability or capacity to respond. This term has also been referred to by these authors in the following ways: "differential responsiveness (as performatively articulated and accountable) to what matters" (Barad 2007, 380), "cultivating collective knowing and 
doing" (Haraway 2016, 34) or "sympoiesis (making-with)" (Haraway 2016, 58), and "rendering each other capable" (Despret 2004, 2016). These notions will be elaborated upon in the course of this paper. Importantly, the ability to respond is not only seen as human but also as a relational capacity by which humans and more than humans are co-constituted through their relationships with each other. A relational ontology, on which response-ability is based, holds that entities or individuals do not pre-exist their relationships - they come into being and are rendered capable through multidirectional relationships.

As we suggest in the paper, a feminist new materialist theoretical framing builds on and moves beyond traditional understandings of critical pedagogies in that responseable pedagogies are not simply examples of the type of learning that can take place when power relations, materiality and entanglement are acknowledged. Response-able pedagogies are also ethico-political practices which incorporate a relational ontology into teaching and learning activities and thus extend their transformative potential. In other words, response-able pedagogies constitute relational processes through which social, political, and material entanglements in higher education (i.e. students, facilitators, discourses, texts, performances, drawings, face-to-face and online comingstogether) are rendered capable through each other to bring about social transformation. Response-able pedagogies may enrich the affordances of critical pedagogies in higher education because they provide new ways of considering what matters and what is often excluded from mattering in higher education pedagogies. The turn to matter within new materialist thought foregrounds the productive qualities of the co-implication of bodies, power, ethics and subjectivities within pedagogical processes. Bodies, power and subjectivities, of course, have been explored previously in education research (e.g. see Youdell 2006), however, the conceptual shift of new materialism that is pedagogically significant is the incorporation of a relational ontology where bodies and matter are entangled and are endowed with agency and complexity and resist being posited as inferior to language or discourse (Hickey-Moody, Palmer and Sayers 2016).

We begin by discussing the theoretical framework of our study, namely, we explain how response-able pedagogies which are located more broadly in feminist new materialism, inform our retrospective look at this transdisciplinary and interinstitutional course. After we outline the design of the course and its context, we examine whether students were able to engage in response-able practices or not, namely, what constrained and enabled their ability to be attentive, responsible, curious, and to render each other capable. Finally, we discuss how this analysis helps reconfigure understandings of critical pedagogies by addressing the question of how response-able pedagogies might support transformative social agendas within the limiting structures of post-apartheid South Africa. The answers to this question have implications beyond the South African context, to other contexts internationally that evidence and reproduce persistent structural inequalities. 


\section{THEORETICAL FRAMEWORK}

\section{Feminist New Materialist Perspectives and Their Contribution}

Feminist and new materialist approaches (e.g. Barad 2007, 2010, 2015; Haraway 1992, 1997, 2016) have, since the early 1990s, been advocating a material turn in philosophy and social theory (Alaimo and Hekman 2008). These approaches emphasise the entanglement of material and discursive realities, human-nonhuman encounters, and engagements with matter. It has been argued that social constructionist approaches (Barad 2011) where language and discourse are taken to be the point of departure, cannot do justice to the material-discursive entanglements of everyday realities. Thus a relational materialist or a diffractive approach (Hultman and Lenz Taguchi 2010; Lenz Taguchi 2012) has been championed as an alternative method of analysis and tool that pays attention to both relationality and material agency.

An important concept of new materialist perspectives is the notion of relational ontology, an ongoing process in which matter and meaning are co-constituted. In new materialism, material-discursive phenomena, matter and meaning are seen as entangled. As Barad notes in her interview with Adam Kleinman on intra-actions for Mousse magazine, matter is not just things or bodies but "substance in its iterative intra-active becoming — not a thing, but a doing, a congealing of agency. It is morphologically active, responsive, generative, and articulate. Mattering is the ongoing intra-active differentiating of the world" (Kleinman 2012, 76). Intra-action, a neologism created by Barad (2007), is a concept that emphasises how bodies and discourses are co-implicated and relational-in the case of this paper, becoming-with each other in the process of teaching and learning. Intra-action assumes that entities or bodies come into being through their relationship, in contrast to the usual notion of interaction which presumes the prior existence of independent entities/agencies.

Barad also equates matter with meaning or sense-making which she refers to as "mattering" or as "material-discursive" (Barad 2007, 2014; Kleinman 2012). For Barad, matter is not just of the head but also of the heart and hands; it has to do with a scholarly engagement with care, social justice and seeing oneself as part of a world. Importantly, then, new materialism raises issues of responsibility and being responsive to each other's becoming-with, or as Barad and Haraway refer to it, response-ability, of a yearning for social justice (Barad 2007) and a rendering capable towards possible worlds (Haraway 1997, 2016). New materialist perspectives do not separate epistemological from ontological and ethical domains-they are deeply ethico-onto-epistemological approaches (Barad 2007, 2014).

Hence feminist new materialism highlights that differences indeed matter in ethical and political terms, not merely as materialities that happen to be present (or absent) and are entangled with discursive realities. The conceptual shift of new materialism that is pedagogically significant is that the co-implications of subjectivities and bodies in the classroom move beyond the boundaries and binaries of who or what may be considered 
"oppressed" or "oppressive." The new materialist focus on intra-active becomings enables us to build on some of the now established debates around critical pedagogies and their transformative potential (e.g. Ellsworth 1989; Giroux 2004; Kumashiro 2002; McLaren 2003), and to extend the possibilities for new openings that support responseability in higher education.

Therefore, new materialism emerges as a methodology, a theoretical framework and a political position that emphasises not only the complex materiality of bodies embedded in power relations (Dolphijn and van der Tuin 2012), but also the new transformative possibilities incorporated in collective knowing, being, doing and making. But to make sense of these transformative possibilities we need to clarify how feminist new materialisms add something valuable rather than rejecting critical pedagogies (see Nitis 2015). For this purpose, we want to highlight two important ideas. First, feminist new materialisms with their troubling of the subject/object binary enable us to see how knowing, being and apprehending what matters come into being through intra-action. Individuals and entities are thus not seen as separate with discrete boundaries, but are rather entangled with each other across space and time. We are all part of the world and cannot assume a distance from it or what Haraway (2016) would refer to as a "god's eye view" from above. In terms of higher education pedagogies, this would trouble the notion of knowledge being located in particular individuals who transmit it to less knowledgeable others. Students, texts, theories, lecturers emanate through their entanglements - subjects and objects do not pre-exist their relationships. Being rendered capable means that there is no pre-existing knowledgeable other but that all are affected and affect the other (both the human and the more than human), becoming-with the other through relationships.

Second, feminist new materialism offers a way of seeing the politics and ethics of higher education pedagogies as relational practices. Donna Haraway $(2008,92)$ refers to this ethics and politics as one of "worlding," involving the richness and responsiveness that comes from species interdependence as a "refusal of innocence and self-satisfaction with one's reasons and the invitation to speculate, imagine, feel, build something better." Being responsive to possibilities of co-flourishing and mutuality in higher education pedagogies in the present and in times to come requires an openness, an ability to risk and to play, rather than following prescriptive rules about how pedagogies should be done (Haraway 2016). This means being prepared to "meet each moment, be alive to the possibilities of becoming" which "is an ethical call, an invitation that is written into the very matter of all being and becoming" (Barad 2007, 396).

\section{The Elements of "Response-able" Pedagogies}

Response-able pedagogies are made possible through the relational practices ${ }^{1}$ of attentiveness, curiosity, responsibility, and being rendered capable, which are referred

1 We view these as enactments rather than as dispositions. Haraway (2016) refers to them as inhabitations or ways of cultivating response-ability. 
to in the new feminist materialist scholarship of Barad, Haraway, and Despret discussed earlier. These ethico-political practices will be elaborated below as we consider them all to be crucial elements of a response-able pedagogy. Each of these relational practices are predicated on the notion that we are part of the world and implicated in everything. There is also the assumption that humans and more than humans are entangled in multidirectional relationships.

\section{Attentiveness}

Why would a response-able pedagogy require the practice of attentiveness? In order to cultivate the ability to respond, one first needs an attentiveness which is finely tuned. Barad sees attentiveness as a major part of her notion of diffractive reading, which requires a close and careful engagement with the fine details of a text. She would see this as a response-able practice of doing justice to what the text is conveying. Attentiveness in pedagogy similarly involves the ability to pay due attention, to read, or listen with discernment and care to what is and what is not being expressed, "activating the sensibility of all our embodied faculties" (Lenz Taguchi 2012, 272). In order to be able to do this, it is necessary to open oneself to being affected by another-whether that other is another human, an animal, an artefact, a text or a space (Massumi 2015). Donna Haraway views attentiveness in the following way: "To hold in regard, to respond, to look back reciprocally, to notice, to pay attention, to have courteous regard for, to esteem: all of that is tied to polite greeting, to constituting the polis, where and when species meet" $(2008,19)$.

This expansive view of attentiveness brings out the importance of recognitionthe respectful or positive regard - and regards attentiveness as a political, public and collective relational practice of interdependent companion species. In higher education pedagogies this would mean polite or courteous regard for the human and more than human and noticing what is significant for the other. Despret (2015a, 2015b) also sees attention as a two-way process, with animals and humans discovering each other's needs through paying attention to each other, and developing mutual bodily languages for understanding each other, leading to attunement. For Haraway, learning to pay attention across species changes who or what the partners become-a relational ontology of "becoming-with." For response-able pedagogies the attunement between what is done and how it is done in the classroom with an openness to multiple needs, leads to a becoming-with the other. Attentiveness for Barad (2007) is a relational process that requires such an openness to meeting the other, with a central concern for justice. She sees it as "the ongoing practice of being open and alive to each meeting, ... so that we might use our ability to respond, our responsibility, to help awaken, to breathe life into ever new possibilities for living justly" (Barad 2007, x).

For a response-able pedagogy then, the engagements across differences and the ways in which they happen are very important — this means the ability to apprehend, 
to listen, to be open and respectful and the ability to inhabit just practices in collective spaces.

\section{Curiosity}

Paying careful attention is necessary to cultivate practices of curiosity, so sorely needed in higher education pedagogies to enliven classrooms. These practices of curiosity help to enable the bodymind to flourish and grow through the risk of opening up to encounters with the unexpected, to create enlarged mentalities. Cultivating curiosity can be likened to Hannah Arendt's training the imagination to go wandering or to go visiting. This is something that Vinciane Despret, according to Haraway (2016), achieves with her whole being - both ontologically and epistemologically, rather than just with her imagination. This is because Despret finds others interesting and goes about her research not presupposing that she knows about others, instead making way for the possibility to be surprised and intrigued through unanticipated encounters. This visiting requires an intense curiosity where "one cultivates the virtue of letting those one visits intra-actively shape what occurs. They are not who/what we expected to visit, and we are not who/ what were anticipated either. Visiting is a subject- and object-making dance" (Haraway $2016,127)$. In terms of a response-able pedagogy, cultivating curiosity is a practice where all are changed in the process of encounters in unanticipated ways, becomingwith each other. The non-human (books, theories, physical and virtual spaces) and the human (lecturers and students) affect and are affected through their entanglements...

\section{Responsibility}

Responsibility or accountability is about how entanglements are enacted-how and what we know, how and what we do in the context of what exists in the world of which we are part - in this case the higher education pedagogical space. Both Haraway (2016) and Barad (2007) remind us that responsibility is ongoing and also never solely located inside disembodied subjects, in dualistic or human relationships but rather in multidirectional relationships including other species and more than human partners. The asymmetrical power differentials implicit in relationships need to be borne in mind when thinking about responsibility and accountability, particularly with regard to pedagogical encounters in higher education. For these feminist materialists, responsibility begins from the acknowledgement that we are all part of the world, and that we cannot distance ourselves from it or assume a stance of innocence in our relationships with others. Barad so aptly elaborates on this non-innocent relationship:

What would it mean to acknowledge that the "able-bodied" depend on the "disabled" for their very existence? What would it mean to take on that responsibility? What would it mean to deny one's responsibility to the other once there is a recognition that one's very embodiment is integrally entangled with the other? (Barad 2007, 158) 
The recognition that difference is embodied and entangled rather than existing in abject others is important for designing ethical curricula that bring together differently positioned disciplines, institutions and humans. Taking responsibility for dependence means a commitment to ourselves and others to avoid what has been referred to as "privileged irresponsibility" where the services of another to meet one's own needs are used but not acknowledged.

\section{Being Rendered Capable}

Rendering each other capable enlarges the competency of all the players-we are constituted through each other-co-teachers, books, theories, students, HEIs, courses etc. However, it is not only humans being rendered or rendering each other capable, sometimes it involves unexpected company. The capacity to respond to the other is an important part of rendering each other capable and this needs to be cultivated for a response-able pedagogy which is a collective process of potentiality and becoming. Rendering each other capable does not happen through duty ethics-feeling that one has to do something — but through the capacity to respond to what matters - as Haraway expresses it, "a kind of luring, desiring, making-with" (in Davis and Turpin 2015, 257). This is a process which involves cultivating ethical (how to flourish together in a complex world of living and dying), ontological (being and becoming, making-with) and epistemological (knowing-with, enlarging each other's thinking) response-abilities.

\section{THE DESIGN OF THE "COMMUNITY, SELF AND IDENTITY” COURSE}

We now turn our attention to the design of the course which we wish to view from the vantage point of a response-able pedagogy — how it did or did not enable the possibility of such a pedagogy.

The course titled "Community, Self and Identity" (CSI) was initiated by academics located at two institutions, which are geographically close to each other, but very differently positioned in the South African higher education landscape. The University of the Western Cape (UWC), an historically disadvantaged black institution (HDBI), continues to struggle with paucity of funding, human and material resources, problematic geopolitical positioning, and the students who study there are largely black and working class (4\% of the students were white in 2012). Stellenbosch University (SU), on the other hand, is an historically advantaged white institution (HAWI), with smaller staffstudent ratios, catering largely for Afrikaans-speaking students and is thus monocultural (68\% white in 2012) (Cooper, D. 2015). Academics from psychology and social work, as well as the director of teaching and learning from one of the HEIs were those that came together to decide what to do regarding the inequities that existed between the institutions and the disciplines (see below for more details). They decided to devise an inter-institutional transdisciplinary course for senior undergraduate (social work and 
occupational therapy) and honours psychology students who were all studying aspects of community and how these relate to self and identity. The anticipated participants on the course were the social work and occupational therapy students at UWC-largely black working-class students in their fourth year of the degree - and the psychology students at SU-largely white middle-class and high achieving students in their honours year. The Community, Self and Identity (CSI) project, as it became known, was set up to investigate whether and how, through dialogue and the exposure to multiple perspectives, both students and academics might be enabled to question dominant knowledges and assumptions about issues of community, self and identity in South Africa. Thus, issues of power, privilege and difference informing academics' and students' professional and institutional positions were central to this project, in the context of apartheid-designed higher education institutions and geographical areas of South Africa which still affect human settlement and movement, with little contact between students and academics across UWC and SU (Bozalek et al. 2010; Bozalek and Biersteker 2010).

Three key motivations informed the development of the course. The first was a desire to address the monoculturalism, segregation and isolation between academics and students across HAWIs and HDBIs; even though the two institutions were relatively close to each other (about $20 \mathrm{kms}$ apart) students and academics rarely visited or had any contact with each other across institutions. Importantly, informal spatial segregation still exists to this day between HEIs, and the teachers and students who inhabit them (Bozalek et al. 2010). The second motivation was to bring students together in a transdisciplinary course which could be taught in more creative ways. Third, there was a desire to trouble the hierarchical positioning of the disciplines of social work, psychology and occupational therapy, and of the historically advantaged and disadvantaged higher education institutions (HAWIs and HDBIs). Social work as a profession was regarded as "less than," as was the HDI, and the designers of the transdisciplinary CSI course wished to develop a curriculum which affirmed these "inappropriate/d others" (Haraway 1992, 299) - the discipline, the institutions and the students who were studying there. This was considered necessary in a system of inequality inherited from an apartheid past which is still deeply affected by Eurocentric notions of what counts as knowledge. This meant that the curriculum needed to be carefully planned to avoid reinforcing and perpetuating negative ways of viewing denigrated professions, institutions and the students who are enrolled in them. In bringing students together across difference, the intentions were to provide opportunities to challenge taken-for-granted assumptions about the other's discipline/institution/histories.

The academics decided to use participatory learning and action (PLA) techniques within the course because they could potentially allow the experiences of black, working-class social work students to be foregrounded and appreciated. PLA techniques are interactive, usually practised in groups and often rely on visual methods, where the participants are asked to draw something and then discuss it with other participants in their groups afterwards (Bozalek and Biersteker 2010). As an approach, PLA, which is part of participatory action research (PAR), views participants themselves as experts 
of their lives, and the educator as a facilitator for amplifying the becoming-with of the participants. PLA techniques can be regarded as a form of arts-based approaches (Bozalek and Biersteker 2010).

The team spent a great deal of time deliberating how best to implement a transinstitutional and transdisciplinary course which would address issues of inequality and privilege across the different institutional contexts. Students studying at HAWIs come from relatively privileged sectors of society; these students have access to better secondary schooling education and literate parents as well as other privileges and resources than their counterparts at HDIs. To address these inequitable relations of power, the team decided that PLA techniques would be a suitable modality for students to begin their engagement with each other. We knew that students from HAWIs and HDBIs had very few opportunities of interacting with each other, due to apartheid legacies of geographical separation which continue to affect interactional patterns of communication in contemporary South Africa. In providing students with opportunities to work collaboratively on the themes of community, self and identity, it was hoped that they would be able to become more aware of differences and inequitable economic, social, political and cultural structures and practices.

The following list of activities (Table 2) shows how the different tasks were designed as relational processes through which social, political, and material entanglements (i.e. students, facilitators, discourses, texts, performances, drawings, face-to-face and online comings-together) were manifested in the course.

Table 1: Outline of CSI module activities

\begin{tabular}{|l|l|l|}
\hline Time-frame & Task & Description \\
\hline First week & First workshop at UWC & $\begin{array}{l}\text { - Introduction to the project } \\
- \text { Training on use of } \\
\text { e-learning platform } \\
\text { - Drawings of community } \\
\text { maps, lifeline and sharing in } \\
\text { cross-institutional and inter- } \\
\text { disciplinary groups }\end{array}$ \\
\hline Second week & $\begin{array}{l}\text { First e-postings from } \\
\text { students }\end{array}$ & $\begin{array}{l}\text { Students post a written } \\
\text { discussion forum, reflecting } \\
\text { on their own drawings made } \\
\text { at the first workshop, as } \\
\text { well as the drawings of one } \\
\text { other student from the other } \\
\text { profession, writing about } \\
\text { what they had learnt about } \\
\text { communities in South Africa. }\end{array}$ \\
\hline
\end{tabular}




\begin{tabular}{|l|l|l|}
\hline Time-frame & Task & Description \\
\hline Third week & $\begin{array}{l}\text { Second e-postings from } \\
\text { students }\end{array}$ & $\begin{array}{l}\text { Students post replies to } \\
\text { comments made by other } \\
\text { students. }\end{array}$ \\
\hline Fourth week & Second workshop at UWC & $\begin{array}{l}- \text { Exercise on identity and } \\
\text { community work } \\
- \text { Input on doing } \\
\text { presentations } \\
- \text { Working in groups on } \\
\text { group project }\end{array}$ \\
\hline
\end{tabular}

In order to design a curriculum that allowed the students to have enlarged views of community, self, and identity, the course design team encouraged engagement with local and international texts that troubled the notions of community, self and identity. They also arranged for local and international artists, poets and differently abled actors to give performances in the process of the course (see Carolissen et al. 2011 for a full description of the use of arts and the effects that this had on the students). The guidelines developed for the final assignment, mentioned in the table above, could also be regarded as providing opportunities for students to show whether their conceptions of community, self and identity, their profession and institution had been enlarged or not from intra-actions with the readings, the drawings and each other during the module. Similar guidelines for writing the essay were provided in all three years. For example, the instructions were given as follows (see Figure 1):

Making use of the literature provided, and your personal experience, complete a short paper (1500 to $\mathbf{2 0 0 0}$ words) reflecting critically on what you have learnt in this module.

In the paper, you should:

- Discuss how the readings have influenced your understanding of notions of 'community', 'self' and 'identity'? Have you learnt something that differs from your previous understanding of these notions?

- What have you learned through working together? Looking back on your initial assumptions about institution and discipline, what do you feel has changed?

- What has been your learning experience? Did you find some of the learning tools, resources and products more useful than others? Give a brief rationale for your opinions. Also comment on the influence, if any, this

Figure 1: Final reflective essay for CSI course 


\section{Ethical Issues}

At the start of the each of the years that the course was offered, during the first workshop, all participants were informed about the nature and aims of the project. There were a total of 282 students over the three years from 2006-2008 across the two HEIs and three disciplines. They were informed that in addition to being a part of the course curriculum, it was also a research project undertaken by the developers of the course. They were told that written consent would be asked of them at the end of the course, once they had generated their written work, and they had the opportunity to decide whether or not they wanted their works to be used for research purposes. They were alerted to the fact that their written works, often of a personal nature, would be posted on the e-learning programme, and thus would be in the public domain (accessible only to those involved in the course as well as the participants). Participants were informed that any written works used for research purposes and publication would be treated anonymously. Most participants gave written consent, but the work of those who did not give consent was not included for analysis.

\section{Project Data}

The project provided a large reservoir of research data. The CSI module included the following:

1. Approximately 90 students per year for three years (2006-2008). In the case where students gave written consent to use their work, which approximately 95 per cent of the students each year did, this comprised of:

- All drawings by participants created during the three contact sessions;

- All written assignments and PowerPoint presentations, using a variety of genres including conversational, reflective and traditional literature-based, which were stored on the electronic learning management system;

- Feedback forms after each workshop and after the module as a whole (thus 4 forms per student);

2. Specific events, for example a video-taped debriefing session with focus groups each year, and participation in a focus group after the first year within a public colloquium on the module, in a panel. This discussion was also transcribed. A group from the first year of the module also presented a paper at an annual national educational conference, which was published as Rohleder et al. (2007).

3. The assessment was moderated each year by an academic from a different university. Her useful reports were included in the data gathered for the evaluation of the module. 
4. A longitudinal study conducted two to three years after students took the module, comprising:

- a quantitative online survey completed by 23 students,

- 18 face-to-face interviews with individual students, and

- two online synchronous chat groups facilitated by an external facilitator using Google Chat as a discussion group forum, with three and four students respectively.

5. Similar data was collected from the academics who participated in the course which was adapted and changed from the CSI course for teachers in higher education across four HEIs in Cape Town from 2010-2012.

We now move on to consider how participants engaged with the course from the perspective of a response-able pedagogy. We read through all the reflective essays of the students and teachers, looking for data which pertains to the elements of attentiveness, curiosity, responsibility and being rendered capable.

\section{STUDENTS' ENGAGEMENT WITH THE COURSE FROM THE PERSPECTIVE OF A RESPONSE-ABLE PEDAGOGY}

In this section of the paper we consider how those who were participants on the course responded to it in terms of a response-able pedagogy - and importantly, what constrained and enabled their responses to the course. We draw on the students' and academic participants' final reflective tasks as the source of data for evidence of a response-able pedagogy.

\section{Attentiveness}

Being in an unfamiliar setting can activate sensibilities of embodied faculties (Lenz Taguchi 2012). The geographical setting for the course heightened the participants' attentiveness as they were required to travel to each other's campuses and comment on their perceptions of the different universities (see Carolissen and Bozalek 2016 for a detailed analysis of their responses to each other's universities). The participants were first required to listen carefully to the instructions about the online and pedagogical tools that were used for the course - the e-learning platform and the PLA techniques. They then had to draw their community maps and rivers of life and engage in a discussion about these with each other in their small inter-disciplinary and inter-institutional groups of six people. Sometimes the facilitators in these groups joined the discussions and other times not. Their drawings were then photographed and put onto the online platform. They continued working in these small groups responding to each other about their community maps and the critical readings they had been given. In their second face-to- 
face meeting, they had to listen to and watch the performances of a poet, a performance artist, or a film and respond to these. They also had to meet with their groups outside of class time to plan a group poster or presentation on the notions of "community," "self" and "identity."

There was much energy and engagement in the activity. Students found it easiest to pay attention to the complex histories of entanglement and in/justice regarding each other's stories related to their community maps and rivers of life. Listening was identified as important to attentiveness:

The discussions that took place in the group gave me the opportunity to learn and grow as a person. It also taught me that people have various opinions and insights and that if you listen for long enough you might learn something very profound and useful. It also taught me not to be judgemental which so many of us are, and taught me to value everyone's opinions, no matter how much they differed from my own one. This is a very useful tool, because being a community psychologist, it is important to have very good listening skills and not just talking skills. It teaches you to use your body parts in the ratio that they were given to you. Two ears and only one mouth, therefore, you should listen twice as much as you talk. (2006, SU psychology, white female, student no. 53)

This student recognises the importance of both the quality and amount of time spent listening in non-judgemental ways for human service professionals such as psychologists.

It was difficult for some students to hear the stories of others, as it unravelled their senses of themselves. The PLA drawings and discussion created an openness to meet the other from a perspective of justice. Sometimes for the first time in their lives, students from privileged backgrounds gained access to the living circumstances of those who experienced marginalisation in terms of access to resources and to the fragility of lives in communities that are confronted with harsh living conditions, including exposure to physical violence and health issues with no recourse to resources to assist with these.

For me, whom grew up in a very privileged and protected neighbourhood, it was a big learning curve to see the needs of Western Cape's less privileged communities through the eyes of people that are more exposed to these communities. (2007, SU psychology, white female, student no. 46)

Others were not so much perturbed but gained new perspectives from hearing others relate their historical trajectories and from the response of others to them:

What I found especially wonderful about the module was the diversity of experience and the opportunity to learn from other's perspectives and also to see my own experience from another's point of view. We often take our backgrounds, experiences and circumstances for granted and it is almost impossible for us to imagine our life being different. However, through the PLA techniques we were forced to take a closer look at what it is that we have had, have accomplished and gone through to get to this point and what it is that we value as being professionals. We were further enriched by the responses of other group members to your own experience as it gave one an objective look at their own life. (2006, SU psychology, white female, student no. 27) 
An important constraint regarding attentiveness is that the students noted that six weeks is too short for entrenched dualisms to be dislodged. In some cases, continued tensions and divisions between the hierarchised differences of institutions, professions and identities continued to play out in various ways:

[A]t the final workshop, I noticed that there was still a division between the members of the two institutions and that some differences seemed to be carved in stone. At times I felt that the members of each institution focused primarily on making their own opinions heard and spent less effort on listening and understanding the opposing arguments. I detected a fair amount of blaming and of putting the responsibility of change on the other group. I feel that this is an area that might demand more attention in the future of this course. (2006, SU psychology, white female, student no. 84)

Generally though, from students' reflective essays across the three years, it was evident that the CSI course enabled a form of attentiveness to the institutions, disciplines and other forms of difference which would not have been possible without the physical contact or the course activities.

\section{Curiosity}

Curiosity or an enlarged mentality entails thinking about and re-imagining concepts. Donna Haraway $(2016,35)$ writes about the possibility of repatterning-developing new patterns of thinking, feeling and doing - and recognising oneself as part of a troubled world. In the CSI course, the critical readings set for the course were designed to make the participants rethink notions of community, self and identity in relation to their own PLA drawings of these concepts and the discussions which emanated about the drawings and readings. The group presentations on the final day of the face-toface sessions of the course and the final reflective essays (Figure 1), suggest that the course had moved people in terms of their conceptions of community, self and identity. Generally, most participants in their reflective essays indicated that they had come to some realisations about how they had previously thought about these notions and the changes that had occurred for them during the course:

The readings challenged my notion of community (which had been geographic)-I now understand community has more relational [2] and sometimes political [3] aspects in addition to the structural aspect. I read more about a "sense of belonging" $[2,4]$ which gave words to some of my experiences as an immigrant to South Africa. As the weeks passed, I returned often to the "belonging" concept and to my own past experiences. (2011, HEI in Cape Town, mechanical engineering female academic, participant no. 14)

When going through with this course and being exposed to students and lecturers as well as literature I feel that my previous definitions were much too narrow, I did not think broadly enough about it, I think the words community, self, and identity are just words taken for granted. However when reading through literature focused on these three words it gave me a new 
perspective and showed me how in depth these aspects can be when critically analysed. (2007, UWC occupational therapy, coloured female, student no. 49)

The course thus led to greater understandings, a broadening of definitions and new perspectives on community, self and identity. Although an expanded vision was reported by the majority of participants, it was evident in their presentations to each other at the end of the course that not all participants had been able to trouble these notions for themselves or their professions. In some cases, for example, their view of each other's profession was further entrenched:

There has been a perception that the psychology profession is superior to that of the social work profession. ... Having completed the project, I feel that there are some students including social work students that perceive social work to be inferior to psychology. (2007, UWC social work, coloured female, student no. 43)

This part of the reflective essay suggests that, in some instances, the students, including those from devalued disciplines such as social work, continued to devalue these professions despite the course designers' intentions.

\section{Responsibility}

The CSI course provided an opportunity for both educators and students to "stay with the trouble" (Haraway 2016) regarding responsibility for their apartheid pasts-although in some cases there was resistance to acknowledging this past (see for example Nicholls et al. 2012). The stark realities which exist in South African society became apparent to students when sharing their drawings with each other. Some students had acquired knowledge of these disparities through studying but had no first-hand experience of them. The effects of seeing the drawings and hearing about these inequities from others is what mattered and often had profound effects on students:

Her drawing of her home and community could not be more different from mine. It captures a world which I have only visited, never lived in. It speaks so eloquently of deprivation, of an extreme lack of resources and yet these are my words, not [hers]. Her drawing of [name of rural town] and mine of Stellenbosch succinctly portray the polarised South African reality: we are a nation of haves and have-nots. (2008, SU psychology, white female, student no. 38)

Some participants, even when interviewed once they were in the workplace two to three years after they had completed the course, reported that it had had a profound and lasting effect on them (see Leibowitz et al. 2012 for explication on this). This is important, as Barad and Haraway remind us that responsibility is ongoing. One of the students when interviewed in the workplace, two years after she had done the course, remarked on how the CSI course had forced her to challenge certain aspects of herself:

Those of us who have learnt to think about things ... must take responsibility and be honest about who "I" or he or she is. It will confront you and make you think about who you are and 
other important and deeper things. The whole CSI module was an extremely challenging project, not just for me, but for all of us, because I had to learn how to cope with being gay and with other student opinions about it, and an understanding of it. Through this challenge when I talked about myself I needed to learn how to cope with student reactions to my sexual orientation. Even though I had accepted myself and know who I am, it was still a challenge because the group was so diverse. (2006, SU psychology, white female, student no. 45, interview)

The above interview retrospectively reveals how the student was subject to prejudice from other students in her group regarding her sexual orientation and for this reason was initially reluctant to reveal this - so she continued to be affected by this. During the course, in her reflective essay, she also expressed an openness and curiosity towards herself and her engagement with others in her group with regard to her decision to reveal her sexuality after some time to the group:

As is most often the case, there was no overtly heterosexist response. But there was a response. One group member expressed surprise; another bravely acknowledged her prejudice, a wellintentioned third member hastened to reassure me that she still respected me, a fourth privately revealed their ambivalence around their own sexuality and the fifth remained silent. I felt moved at how hard my group worked to take on board this newly visible aspect of my identity. And saddened that it required work at all. (2006, SU psychology, white female, student no. 45)

Here it is evident that the responsibility does not lie within the student herself, but within the relationality of the group. Realising the importance of being confronted with aspects that may be discomforting to deal with in close proximity was an opportunity created by the course.

\section{Being Rendered Capable}

The PLA drawings and the discussions which ensued both face-to-face and online, made it possible for students from very different backgrounds to assist each other in collective knowing and doing to be able to recognise and experience the effects of difference, particularly regarding the effects of differential economic living arrangements and access to resources and how these matter for student lives. Students attending the course from different institutional and disciplinary backgrounds reported that the CSI course gave them opportunities to disrupt boundaried notions of self and interrogate prejudices:

through interactions like these one comes to view how it is possible to transgress boundaries ... it is difficult to let go of deep entrenched notions - stereotypes, prejudices etc. therefore opportunities like this course and an exercise like this [the PLA exercise] becomes a vital tool of exploration and interrogation of those beliefs. (2006, SU psychology, coloured male, student no. 29)

The CSI course was structured in such a way that there was a lot of dialogue and feedback to and from each participant and from their facilitators. Furthermore, the making of the drawings - the intra-action between the non-human and human - call forth new ways 
of seeing the world for participants, and new ways of being rendered capable with and through the other. Intra-actions enable mutual constitutions of entangled agencieshuman and non-human - which only exist in their entanglement, not as individual elements.

The quote below shows how intra-actions in the form of feedback and discussion with the facilitator, group members and class members, using the online platform, render the student capable of extended knowledge and understanding:

For me it has been very enriching and instructive to get feedback from our facilitator and group members on my writing and reflections and also to read the works of my fellow students. I see it as simultaneously advantageous with the open discussions in class and at the workshops; this has helped me to extend my knowledge and understanding of the different professions, different communities in South Africa and the country's cultural and historical background (2006, SU psychology, white Norwegian female, student no. 61)

The importance of seeing the other in an affirmative light-whether this other was the higher education disadvantaged institution (HDI), the discipline (social work) or devalued social identities (black, working class, women) was one of the primary reasons for constructing the course. One of the effects of engaging across difference was that students were being rendered capable through their discomfort of engaging with the other.

[I]t is not often that we are literally thrown together with people from diverse backgrounds to actually have first-hand experience of diversity. I feel that coming together with the UWC students, not only during the course but specifically for the presentation, forced us to take a step out our comfort zones, and really experience diversity. (2008, SU psychology, female white, student no. 79)

The UWC students on the other hand had to reconsider their feelings of inferiority, and their worries about racism when coming into contact for the first time with the psychology students from Stellenbosch University:

Before the workshop I was very worried especially when I think of the student[s] from Stellenbosch University. I use to have stereotyping thinking that student[s] from Stellenbosch are racist. The day we been waiting for actually came I really didn't believe what I saw, the workshop was different from what I expected. The way we interacted with the students from Stellenbosch was good. (2008, UWC social work, Xhosa-speaking female, student no. 17)

Being open to the other, learning to pay attention and be responsive to asymmetrical positions, and in so doing confronting oneself, is an important part of rendering each other capable as students - as Barad $(2007,391)$ notes, "[s]ubjectivity is not a matter of individuality but a relation of responsibility to the other."

Through their intra-actions, students were rendered more capable to recognise the politics and history which in some cases they had not been fully cognisant of - this only happened in the becoming-with each other. They would not have been able to achieve 
this without the intertwinings of the drawings, the smell, touch, sights and physical contact with each other's campuses. Through these engagements with the other, with matter and meaning, the students were rendering each other capable in terms of their historical and political understandings of the effects of apartheid. In this way they were able to learn about themselves with and through the other, co-constituting each other's subjectivities through matter and meaning.

\section{CONCLUSIONS AND IMPLICATIONS: TOWARDS ETHICO-POLITICAL RESPONSE-ABLE PEDAGOGIES}

What can we learn about response-able pedagogies from the CSI course in terms of the ethico-political practices we have chosen to concentrate on? The CSI course, emerging from the legacy of apartheid with its geographical separateness, was set up to engender a more heterogeneous history of South African higher education than its monocultural and geographically separated institutions had afforded. The course provided practical, playful and sometimes risky and discomforting ways of engaging with the other. There were many opportunities in the course for attentiveness, curiosity, responsibility and rendering each other capable to happen, but also constraints in some instances that explain why these practices did not happen, as we have indicated in the previous part of the paper. For example, there were instances where prejudices about the other disciplines, social categories or institutions were further entrenched. But generally, through the active doing together (sympoiesis) of drawing and coming together and the discussions in face-to-face and online spaces, students became aware of their entangled political histories. In some cases, this led to an awareness of responsibility for and a capacity to respond to the inherited past which continues to play out in the present and future.

The different pedagogical activities as part of the apparatus used in the curriculum, interfered with the bodyminds of the participants, enabling new thoughts and intraactions with each other for the participants. However, mere recognition of power relations, materiality and entanglement is not enough; an openness to listen, question, challenge, and reconfigure concepts (community, self and identity) together is necessary for a response-able pedagogy to happen (cf. Ladson-Billings and Tate 1995). The course set out to provide possibilities for ethical and care-full ways of paying attention to what mattered in participants' lives, recognising intersections of past, present and future (Bozalek et al. 2010), whilst at the same time casting "our lives for some ways of life and not others" (Haraway 1997, 36). The CSI course is a powerful reminder of the insight that "[t]he past is never closed, never finished once and for all, but there is no taking it back, setting time aright, putting the world back on its axis. There is no erasure finally" (Barad 2010, 264). The course provided an opportunity not just to confront the past and future but for affective engagement with the "entangled relationalities of inheritance that 'we' are, to acknowledge and be responsive to the contemporaneity 
of the present" (Barad 2010, 264). The CSI course is an example of a response-able pedagogy developed to address issues of continuing inequalities between differently placed disciplines, higher education institutions, students and academics.

The analysis in this paper helps reconfigure understandings of critical pedagogies by addressing the question of how response-able pedagogies might support transformative social agendas within the limiting structures of post-apartheid South Africa. The answers to this question have two important implications beyond the South African context for other contexts internationally that evidence and reproduce persistent structural inequalities. First, it is important we clarify that response-able pedagogies are not "new" forms of critical pedagogies. Rather, they are existing critical pedagogies which pay explicit attention to attentiveness, curiosity, responsibility and rendering each other capable. Response-able pedagogies mark a valuable intervention in the broad domain of critical pedagogy by focusing more specifically on identifying and examining whether pedagogies evoke ethico-political responses that incorporate a relational ontology in teaching and learning. What distinguishes response-able pedagogies is their emphasis on materiality (i.e. embodied self-expression, the use of multiple media) that creates pedagogical opportunities for enriching response-ability towards individuals who suffer gross inequalities. For example, attentiveness to the social and political vulnerability of others (due to apartheid or other unequal social structures) is an important component of response-able pedagogies in higher education. Students are rendered capable to establish and maintain this attentiveness when they begin to question and challenge arguments based on essentialist categories and binaries such as us/them, oppressors/ oppressed, or good/evil.

Second, response-able pedagogies are cultivated when students are given opportunities to realise their entanglement in social and political conditions (structural inequalities, material conditions, etc.) that give rise to suffering and inequality and acknowledge some sort of human and beyond human connection between themselves and others, specifically what it might mean for one to encounter various forms of injustice. The recognition of the multiple ways in which (in)equality and (in)justice are assigned differently and have ethical and political implications is clearly relevant to the issue of how students are rendered capable through each other to engage in transformative action. The purpose of response-able pedagogies in higher education is to create pedagogical spaces in which teachers and students can become response-able to each other and offer an alternative option to that of essentialist categorisations of community, self, and identity. The process of dissolving such categorisations is a matter of observing very carefully the ethical and political consequences of the pedagogical interventions that are being designed and performed. These interventions need to be conducted in sensitive and critical ways.

In conclusion, it is necessary, as Haraway (2016) has noted, to "stay with the trouble"; there is no innocent starting point - we are all always and already implicated in our entanglements with everything. As Kathrin Thiele notes "ethico-onto-epistemologically 
it will matter at every moment which knowledges get produced, which thinking populates the world and which cuts are made" (Thiele 2014, 205). Response-able pedagogies and the ethico-political practices associated with them can enable a troubling of inside/ outside, me/you, them/us and create "the surprise, the interruption, by the stranger (within) re-turning unannounced" (Barad 2014, 178).

\section{REFERENCES}

Alaimo, S., and S. Hekman, eds. 2008. Material Feminisms. Bloomington: Indiana University Press.

Bozalek, V., and L. Biersteker. 2010 “ "Exploring Power and Privilege Using Participatory Learning and Action Techniques." Social Work Education 29 (5): 551-72. https://doi.org/10.1080/02615470903193785

Bozalek, V., and C. Boughey. 2012. "(Mis)Framing Higher Education in South Africa." Social Policy and Administration 46 (6): 688-703.

Bozalek, V., R. Carolissen, L. Nicolls, B. Leibowitz, L. Swartz, and P. Rohleder. 2010. "Engaging with Difference in Higher Education through Collaborative Inter-Institutional Pedagogical Practices." South African Journal of Higher Education 24 (6): 1023-1037.

Bozalek, V., B. Leibowitz, R. Carolissen, and M. Boler, eds. 2014. Discerning Critical Hope in Educational Practices. London: Routledge.

Bozalek, V., and W. McMillan. 2016. "Diffracting Learning/Teaching Entanglements: A South African Vice-Chancellor's Perspective." In Theorising Learning to Teach in Higher Education, edited by B. Leibowitz, V. Bozalek and P. Kahn, 43-58. London: Routledge.

Bozalek, V., and M. Zembylas. 2016. "Diffraction or Reflection? Sketching the Contours of Two Methodologies in Educational Research." International Journal of Qualitative Studies in Education 30 (2): 111-27. https://doi.org/10.1080/09518398.2016.1201166

Barad, K. 2007. Meeting the Universe Halfway: Quantum Physics and the Entanglement of Matter and Meaning. Durham: Duke University Press. https://doi.org/10.1215/9780822388128

Barad, K. 2010. "Quantum Entanglements and Hauntological Relations of Inheritance: Dis/Continuities, SpaceTime Enfoldings, and Justice-to-Come." Derrida Today 3 (2): 240-68. https://doi.org/10.3366/ drt.2010.0206

Barad, K. 2011. "Erasers and Erasures: Pinch's Unfortunate 'Uncertainty Principle."' Social Studies of Science 41 (3): 443-54. https://doi.org/10.1177/0306312711406317

Barad, K. 2012. "Nature’s Queer Performativity." Kvinder, Køn og Forskning/Women, Gender and Research $1(2): 25-53$.

Barad, K. 2015. "On Touching - The Inhuman That Therefore I Am (V.1.1)." In Power of the Material/ Politics of Materiality, edited by S. Witzgall and K. Stakemeier, 153-64. Zurich: Diaphanes eTexT. 
Carolissen, R., V. Bozalek, L. Nicholls, B. Leibowitz, L. Swartz, and P. Rohleder. 2011. "bell hooks and the Enactment of Emotion in Teaching and Learning across Boundaries: A Pedagogy of Hope?" South African Journal of Higher Education 25 (1): 157-67.

Carolissen, R., and V. Bozalek. 2016. "Addressing Dualisms in Student Perceptions of a Historically White and Black University in South Africa." Race Ethnicity and Education 20 (3): 344-57. https://doi.org /10.1080/13613324.2016.1260229

Cooper, C. 2015. "Critical Pedagogy in Higher Education." In Socially Just, Radical Alternatives for Education and Youth Work Practice, edited by C. Cooper, S. Gormally and G. Hughes, 39-64. Basingstoke: Palgrave Macmillan. https://doi.org/10.1057/9781137393593

Cooper, D. 2015. "Social Justice and South African University Student Enrolment Data by 'Race', 19982012: From ‘Skewed Revolution' to ‘Stalled Revolution.'” Higher Education Quarterly 69 (3): 23762. https://doi.org/10.1111/hequ.12074

Davis, H., and E. Turpin, eds. 2015. Art in the Anthropocene. Encounters among Aesthetics, Politics, Environments and Epistemologies. London: Open Humanities Press.

Despret, V. 2004. "The Body We Care for: Figures of Anthropo-zoo-genesis.” Body and Society 10 (2-3): 111-34. https://doi.org/10.1177/1357034X04042938

Despret, V. 2015a. “We Are Not So Stupid ... Animals Neither.” Angelaki 20 (2): 153-61. https://doi.org/ 10.1080/0969725X.2015.1039855

Despret, V. 2015b. “Who Made Clever Hans Stupid?” Angelaki 20 (2): 77-85. https://doi.org/10.1080/096 9725X.2015.1039843

Despret, V. 2016. What Would Animals Say if We Asked the Right Questions. Minneapolis: University of Minnesota Press. https://doi.org/10.5749/minnesota/9780816692378.001.0001

Despret, V., and M. Meuret. 2016. "Cosmoecological Sheep and the Arts of Living on a Damaged Planet." Environmental Humanities 8 (1): 24-36. https://doi.org/10.1215/22011919-3527704

Dolphijn, R., and I. van der Tuin. 2012. New Materialism: Interviews and Cartographies. Michigan: Open Humanities Press. https://doi.org/10.3998/ohp.11515701.0001.001

Ellsworth, E. 1989. "Why Doesn't This Feel Empowering? Working through the Repressive Myths of Critical Pedagogy." Harvard Educational Review 59: 297-324. https://doi.org/10.17763/ haer.59.3.058342114k266250

Freire, P. 2000. Pedagogy of the Oppressed. New York: Continuum.

Giroux, H. A. 2004. "Critical Pedagogy and the Postmodern/Modern Divide: Towards Pedagogy of Democratization." Teacher Education Quarterly 31 (1): 132-53.

Haraway, D. 1992. "The Promises of Monsters: A Regenerative Politics for Inapproporiate/d Others." In Cultural Studies, edited by L. Grossberg, C. Nelson and P. A. Treichler, 295-337 New York: Routledge. 
Haraway, D.1997.Modest_Witness@SSecond_Millenium: FemaleMan_Meets_OncoMouse : Feminism and Technoscience. New York: Routledge.

Haraway, D. 2008. When Species Meet. Minneapolis: University of Minnesota Press.

Haraway, D. 2016. Staying with the Trouble: Making Kin in the Chthulucene. Durham: Duke University Press. https://doi.org/10.1215/9780822373780

Hickey-Moody, A., H. Palmer, and E. Sayers. 2016. "Diffractive Pedagogies: Dancing across New Materialist Imaginaries." Gender and Education 28 (2): 213-29. https://doi.org/10.1080/09540253 .2016 .1140723

Hultman, K., and H. Lenz Taguchi. 2010. "Challenging Anthropocentric Analysis of Visual Data: A Relational Materialist Methodological Approach to Educational Research." International Journal of Qualitative Studies in Education 23 (5): 525-42. https://doi.org/10.1080/09518398.2010.500628

Juelskjær, M., and N. Schwennesen. 2012. "Intra-Active Entanglements: An Interview with Karen Barad." Kvinder, Koen og Forskning 21 (1-2): 10-23.

Kleinman, A. 2012. “Intra-actions: Interview with Karen Barad.” Mousse 34: 76-81.

Kumashiro, K. K. 2002. "Against Repetition: Addressing Resistance to Anti-Oppressive Change in the Practices of Learning, Teaching, Supervising, and Researching." Harvard Educational Review 72 (1): 67-92. https://doi.org/10.17763/haer.72.1.c1161752617k46v6

Ladson-Billings, G., and W. F. Tate IV. 1995. “Toward a Critical Race Theory of Education.” Teachers College Record 97 (1): 47-68.

Leibowitz, B., L. Swartz, V. Bozalek, R. Carolissen, L. Nicholls, and P. Rohleder, eds. 2012. Community, Self and Identity: Educating South African Students for Citizenship. Cape Town: HSRC Press.

Lenz Taguchi, H. 2010. Going Beyond the Theory/Practice Divide in Early Childhood Education: Introducing an Intra-Active Pedagogy. London: Routledge.

Lenz Taguchi, H. 2012. “A Diffractive and Deleuzian Approach to Analysing Interview Data." Feminist Theory 13 (3): 265-81. https://doi.org/10.1177/1464700112456001

Martin, G. 2017. “Scaling up Critical Pedagogy in Higher Education.” Critical Studies in Education 58 (1): 1-18. https://doi.org/10.1080/17508487.2015.1115417

Massumi, B. 2015. Politics of Affect. Cambridge: Polity.

McLaren, P. 2003. Life in Schools: An Introduction to Critical Pedagogy in the Foundations of Education. 4th ed. Boston: Allyn and Bacon.

Moje, E. 2007. "Developing Socially Just Subject-Matter Instruction: A Review of the Literature on Disciplinary Literacy Teaching". Review of Research in Education 31: 1-44. https://doi. org/10.3102/0091732X07300046001

Nicholls, L., P. Rohleder, V. Bozalek, C. Carolissen, B. Leibowitz, and L. Swartz. 2012. "Apartheid Was Your Past Not Mine." In Community, Self and Identity: Educating South African Students for 
Citizenship, edited by B. Leibowitz, L. Swartz, V. Bozalek, R. Carolissen, L. Nicholls and P. Rohleder, 73-86. Cape Town: HSRC Press.

Nitis, M. 2015. "Feminist Materialisms in Class: Learning without Masters." In Teaching with Feminist Materialisms: Teaching with Gender. European Women's Studies in International and Interdisciplinary Classrooms, edited by P. Hinton and P. Treusch, 111-22. Utrecht: Atgender.

Rohleder, P., W. Fish, A. Ismail, L. Padfield, and D. Platen. 2007. "Dealing with Diversity in a Virtual Learning Community Across Two South African Universities." South African Journal of Higher Education 21 (7): 893-918.

Rohleder, P., L. Swartz, V. Bozalek, R. Carolissen, and B. Leibowitz. 2008. "Community, Self and Identity: Participatory Action Research and the Creation of a Virtual Community across Two South African Universities." Teaching in Higher Education 13 (2): 131-43. https://doi. org/10.1080/13562510801923187

Thiele, K. 2014. "Ethos of Diffraction: New Paradigms for a (Post)Humanist Ethics.” Parallax 20 (3): 202-16. https://doi.org/10.1080/13534645.2014.927627

Youdell, D. 2006 Impossible Bodies, Impossible Selves: Exclusions and Student Subjectivities. Dordrecht: Springer. 